\section{Exogenous Abscisic Acid Increases the Anthocyanin Concentration of Berry and Juice from 'Isabel' Grapes (Vitis labrusca L.)}

\author{
Renata Koyama, Adriane Marinho de Assis, Lilian Yukari Yamamoto, \\ Wellington Fernando Borges, and Rogério de Sá Borges \\ Department of Agronomy, Londrina State University, Celso Garcia Cid \\ Road, km 380, P.O. Box 10.011, ZIP 86057-970, Londrina, PR, Brazil
}

\section{Sandra Helena Prudêncio \\ Department of Science and Food Technology, Londrina State University, Celso Garcia Cid Road, km 380, P.O. Box 10.011, ZIP 86057-970, Londrina, PR, Brazil}

\section{Sergio Ruffo Roberto ${ }^{1}$ \\ Department of Agronomy, Londrina State University, Celso Garcia Cid Road, km 380, P.O. Box 10.011, ZIP 86057-970, Londrina, PR, Brazil}

Additional index words. berry color, grape juice, plant growth regulator, polyphenols

\begin{abstract}
Vitis labrusca grapes are widely cultivated in some countries such as Brazil and the United States, especially for juice production. 'Isabel' is one of the main cultivars because of its high production and disease tolerance, but the juice is deficient in color. The objective of this study was to evaluate the effect of timing and concentration of $(S)$-cisabscisic acid $(S$-ABA), a specific isomer of abscisic acid applied to 'Isabel' grapes, aiming to increase anthocyanin accumulation and to improve juice quality. The trial was conducted on two consecutive seasons (2011 and 2012) in a commercial vineyard located in Maringa, PR, Brazil. The vines were trained in an overhead trellis system and spaced at $4.0 \times 1.0 \mathrm{~m}$. The statistical model used was a randomized block design with four replications and five treatments: control; $S$-ABA at $200 \mathrm{mg} \cdot \mathrm{L}^{-1}$ at 7 days after veraison (DAV); $S$-ABA at $400 \mathrm{mg} \cdot \mathrm{L}^{-1}$ at $7 \mathrm{DAV} ; S$-ABA at $200 \mathrm{mg} \cdot \mathrm{L}^{-1}$ at $7 \mathrm{DAV}+200 \mathrm{mg} \cdot \mathrm{L}^{-1}$ at 15 days after the first application (DAFA); and $S$-ABA at $400 \mathrm{mg} \cdot \mathrm{L}^{-1}$ at $7 \mathrm{DAV}+400 \mathrm{mg} \cdot \mathrm{L}^{-1}$ at 15 DAFA. There were no significant differences between treatments in relation to berry or cluster size or weight. $S$-ABA application resulted in increased anthocyanin concentrations in both berries and juices, mainly when $400 \mathrm{mg} \cdot \mathrm{L}^{-1}$ was applied. Sensory analysis also revealed the efficiency of this plant growth regulator to promote better acceptance of grape juices. Thus, a single application of $S$-ABA at $400 \mathrm{mg} \cdot \mathrm{L}^{-1}$ at $7 \mathrm{DAV}$ is sufficient to increase the anthocyanins concentration of 'Isabel' grapes, improving the acceptance of juice by consumers.
\end{abstract}

American grapes are widely cultivated in some areas of the world such as Brazil and the United States, mainly for grape juice production as well as for the fresh market. 'Isabel', syn. 'Isabella', grape (Vitis labrusca L.) is one of the most important American cultivars as a result of its high productivity and disease tolerance (Nixdorf and Hermosín-Gutiérrez, 2010).

However, the juice obtained from this cultivar is deficient in color because of a lack of pigments, needing it to be blended with juices from other pigment-producing grapes. These pigment-producing cultivars, as a rule, are less productive than 'Isabel'. For this

Received for publication 18 Dec. 2013. Accepted for publication $10 \mathrm{Feb} .2014$.

We thank CAPES and CNPq for financial support. ${ }^{1}$ To whom reprint requests should be addressed; e-mail sroberto@uel.br. and all tones of red colors found in flowers, fruits and some leaves, stems, and roots of plants (Markakis, 1982). The amount and composition of this flavonoid in grapes differ according to species, cultivar, maturity, and climatic conditions (Segade et al., 2008).

The accumulation of anthocyanins, which starts from veraison (the onset of grape ripening), is responsible for the intensity of the color of berries and appears to be regulated, at least in part, by abscisic acid (ABA) (Ban et al., 2003; Hiratsuka et al., 2001; Owen et al., 2009). Studies have shown that exogenous ABA treatment of hybrid grapes such as 'Kyoho' and 'Olimpia' (Vitis vinifera $\times$ $V$. labrusca) can increase skin anthocyanin concentrations (Han et al., 1996; Kataoka et al., 1982; Lee and Tomana, 1980; Matsushima et al., 1989). The high cost of ABA synthesis by chemical companies did not justify its use in agriculture (Cantín et al., 2007). Recently, a method has been developed for the biological production of $S$-ABA, a specific isomer of ABA, using the Botrytis cinerea fungus, making the production process economically viable for agricultural use (Owen et al., 2009; Siewers et al., 2006). Since then, the effects of $S$-ABA have been tested basically on $V$. vinifera table grapes (Peppi et al., 2007; Peppi and Fidelibus, 2008; Roberto et al., 2012, 2013), but the effect of this plant growth regulator on $V$. labrusca grapes with lack of pigmentation used for whole juice production was not known, especially those grown in warm climate areas.

The objective of this study was to evaluate the effect of treatments consisting of different concentrations of $S$-ABA at different times over the final phase of ripening after veraison on 'Isabel' grape, aiming to increase the accumulation of anthocyanins in berry and juice.

\section{Materials and Methods}

Grapevines and growing conditions. This study was conducted in a commercial vineyard of own-rooted 'Isabel' grapes (Vitis labrusca L.) from 11-year-old vines belonging to the Intervin ${ }^{\circledR}$ winery, located in Maringá, state of Paraná (PR), Brazil (lat. $23^{\circ} 25^{\prime}$ $\mathrm{S}$, long. $51^{\circ} 57^{\prime} \mathrm{W}$, altitude $542 \mathrm{~m}$ ), on two consecutive crop seasons, 2011 and 2012. According to the Köppen classification, the climate is type Cfa, i.e., subtropical climate with an average temperature in the coldest month below $18^{\circ} \mathrm{C}$ and average temperature in the warmest month above $22{ }^{\circ} \mathrm{C}$. The maximum temperature is $31{ }^{\circ} \mathrm{C}$ and the average annual rainfall is $1596 \mathrm{~mm}$ with a tendency of concentrated rainfall in summer months.

The vines were trained on overhead trellis and spaced $4.0 \times 1.0 \mathrm{~m}$ apart. Pruning was performed to leave two to three buds per spur. Subsequently, $5 \%$ hydrogen cyanamide was applied to the buds to induce and standardize sprouting. During the trials, the standard regional cultivation practices with regard to nutrition, weed control, and pest and disease management were used. 
The effects of the plant growth regulator $S$-ABA applied at different concentrations and times on the grape clusters were evaluated. $S$-ABA, at an active concentration of $100 \mathrm{~g} \cdot \mathrm{L}^{-1}$, was supplied by Valent BioSciences Corporation ${ }^{\circledR}$ (Libertyville, IL).

Treatments and experimental design. The following treatments were tested: 1) control (no application); 2) $\mathrm{S}$-ABA at $200 \mathrm{mg} \cdot \mathrm{L}^{-1}$ at 7 DAV; 3 ) $S$-ABA at $400 \mathrm{mg} \cdot \mathrm{L}^{-1}$ at $7 \mathrm{DAV}$; 4) $S$-ABA at $200 \mathrm{mg} \cdot \mathrm{L}^{-1}$ at $7 \mathrm{DAV}+200 \mathrm{mg} \cdot \mathrm{L}^{-1}$ at 15 DAFA; and 5) $\mathrm{S}-\mathrm{ABA}$ at $400 \mathrm{mg} \cdot \mathrm{L}^{-1}$ at $7 \mathrm{DAV}+400 \mathrm{mg} \cdot \mathrm{L}^{-1}$ at $15 \mathrm{DAFA}$.

The randomized blocks design was used as a statistical model with five treatments and four replicates with five vines per plot. Fifteen representative clusters in each plot were marked before the application of treatments for further evaluation.

For treatment applications, clusters were sprayed in the morning using a knapsack sprayer at a pressure of $568.93 \mathrm{psi}$ (39.22 bar) with JA1 hollow cone nozzle tips at a volume of $800 \mathrm{~L} \cdot \mathrm{ha}^{-1}$ to provide complete and uniform coverage. In addition, $0.3 \mathrm{~mL} \cdot \mathrm{L}^{-1}$ of Break-Thru $^{\circledR}$ (Evonik Industries, Germany), a non-ionic surfactant, was added to all treatments.

Berry sampling and fruits analysis. In both crop seasons, clusters of each plot were manually harvested when soluble solids reached around $16{ }^{\circ}$ Brix. For each plot, 90 berries were collected for physicochemical analysis with two berries taken from the upper, middle, and bottom regions of each marked cluster.

The physical characteristics of grapes were evaluated by determining the mass $(\mathrm{g})$ and diameter $(\mathrm{mm})$ of berries and the weight (g) and length $(\mathrm{cm})$ of clusters using a scale and a digital caliper.

Berry color was analyzed using a colorimeter Minolta ${ }^{\circledR}$ CR-10 to obtain the following variables from the equatorial portion of berries ( $\mathrm{n}=2$ per berry): $L^{*}$ (lightness), $C^{*}$ (chroma), and $h^{\circ}$ (hue) (Cantín et al., 2007). Lightness values may range from 0 (black) to 100 (white). Chroma indicates the purity or intensity of color, the distance from gray (achromatic) toward a pure chromatic color, and is calculated from the $a^{*}$ and $b^{*}$ values of the CIELab scale system, starts from zero for a completely neutral color, and does not have an arbitrary end, but intensity increases with magnitude. Hue refers to the color wheel and is measured in angles; green, yellow, and red correspond to $180^{\circ}, 90^{\circ}$, and $0^{\circ}$, respectively (Lancaster et al., 1997; MacGuire, 1992; Peppi et al., 2006).

Grape juice production. Whole grape juices from treatment plots were produced by the Welch process (not from concentrate grape juice), which consists of extracting the juice by steam entrainment using a stainless steel extraction pot with a 7-kg capacity (Hauber Macanuda $^{\circledR}$, PSM-07 CF) without any added enzyme (Borges et al., 2013). For this extraction, a sample of $4 \mathrm{~kg}$ of clusters from each plot was used, producing an average of $2 \mathrm{~L}$ of whole juice. At first, the bottom section of the steamer juicer pot was filled with water and the heat was turned on high The 4-kg washed grape samples were placed in the top section of the steamer and the basket was filled all the way to the top, and the lid was put on. After $45 \mathrm{~min}$, all grape juice was drained into the middle section of the steamer and then bottled at warm temperature $\left(75^{\circ} \mathrm{C}\right)$ into sterilized polyethylene containers with lids and a capacity of $1 \mathrm{~L}$. After cooling, juice bottles were stored in the refrigerator at $4{ }^{\circ} \mathrm{C}$ for further anthocyanin, polyphenol, and sensory analyses.

Anthocyanin extraction. The concentrations of total anthocyanins of berries and juices of all treatments were carried out according to Clemente and Galli (2013). For total anthocyanin extraction from berries, samples of $50 \mathrm{~g}$ of berries per plot were used. Samples were macerated and homogenized with $200 \mathrm{~mL}$ of extracting solution $(70 \mathrm{~mL}$ of ethanol $70 \%$ and $30 \mathrm{~mL}$ of $\mathrm{HCl} 0.1 \%, \mathrm{pH} 2.0$ ) for $2 \mathrm{~min}$ in a blender, then placed in a beaker covered with parafilm and aluminum foil, and extracted in darkness for $12 \mathrm{~h}$ at $4{ }^{\circ} \mathrm{C}$. Afterward, a filtration was made, transferring the content to a $250-\mathrm{mL}$ volumetric flask and completing it with an extracting solution. An aliquot of $2.0 \mathrm{~mL}$ was taken from the stock solution at $4 \pm 0.5^{\circ} \mathrm{C}$ to a volumetric flask of $25 \mathrm{~mL}$, completing the volume with extracting solution and leaving it at room temperature in darkness for $2 \mathrm{~h}$ The extracting solution was used as a blank. For total anthocyanin extraction from grape juices, samples of $50 \mathrm{~mL}$ of whole juice per plot were used. The absorbance of each sample from berries and juices was determined at $535 \mathrm{~nm}$ using a spectrophotometer (Thermo Scientific; Genesys $^{\mathrm{TM}}$, 10S ultraviolet-Vis). Readings were expressed as milligrams of total anthocyanins as malvidin-3-glucoside per $100 \mathrm{~g}$ of berries $(\mathrm{mg} / 100 \mathrm{~g})$ and per liter of juice $\left(\mathrm{mg} \cdot \mathrm{L}^{-1}\right)$.

Polyphenol extraction. The concentrations of total polyphenols of berries and juices were determined by spectrophotometric Folin-Ciocalteau method (Borges et al., 2013; Singleton et al., 1999). For total polyphenol extraction from berries (pulp and skin), samples of 30 berries per plot were macerated and then $5 \mathrm{~g}$ were homogenized with $50 \mathrm{~mL}$ of ethanol $50 \%$ in a blender during $2 \mathrm{~min}$ and centrifuged at $3500 \mathrm{rpm}$ during $5 \mathrm{~min}$. An aliquot of $0.2 \mathrm{~mL}$ of the extract was mixed with $1.8 \mathrm{~mL}$ of distilled water and $10 \mathrm{~mL}$ of 10 -fold diluted FolinCiocalteau reagent. After $30 \mathrm{~s}$ to $8 \mathrm{~min}, 8 \mathrm{~mL}$ of $7.5 \%$ of $\mathrm{Na}_{2} \mathrm{CO}_{3}$ solution was added. All test tubes with the mixture were shaken for $10 \mathrm{~s}$ on the vortex and kept in darkness during $2 \mathrm{~h}$. For total polyphenol extraction from grape juices, samples of $5 \mathrm{~mL}$ of whole juice per plot were used. Absorbance of each sample from berries and juices was measured after $15 \mathrm{~min}$ at $765 \mathrm{~nm}$ using a spectrophotometer (Thermo Scientific; Genesys ${ }^{\mathrm{TM}}$, 10S ultraviolet-Vis) against a blank sample. The blank sample was prepared with water instead of the extract. Determination of total polyphenol was calculated from the calibration curve obtained with gallic acid. Readings were expressed as $\mathrm{mg} / 100 \mathrm{~g}$ of berries and $\mathrm{g} \cdot \mathrm{L}^{-1}$ of juice (gallic acid equivalents).

Sensory analysis of grape juices. For evaluation of juices obtained in both crops, a randomized block experimental design using 70 untrained tasters was adopted. Evaluations were performed in individual booths with special daylight lighting in the Sensory Analysis Laboratory. The color, aroma, flavor, body, and overall acceptability of the juice samples were evaluated using a 9-point hedonic scale, which ranged from "dislike extremely (1)" to "like extremely (9)" (Villanueva et al., 2005). Samples were served at $4{ }^{\circ} \mathrm{C}$ in transparent acrylic glasses at a volume of $40 \mathrm{~mL}$ per sample. Each evaluator received the five treatment samples, coded with random three-digit numbers in randomized order. Drinking water at room temperature was served to the panelists for mouth cleaning before and between evaluations of grape juice samples.

Statistical analysis. Means were subjected to analysis of variance and compared using the Scott-Knott test at 5\% probability. Because results observed for each crop season were quite similar, means of the combined crops were considered for discussion.

\section{Results and Discussion}

There were no significant differences between treatments in relation to grape physical characteristics such as mass and diameter of berries or mass and length of clusters (Table 1). It shows that $S$-ABA has no effect on these characteristics of 'Isabel' grape, i.e., the exogenous application of this plant growth regulator does not modify the vineyard yield. The means observed are similar to those obtained by Sato et al. (2009), who described the main production characteristics of 'Isabel' grapes for processing. Similarly, in studies conducted on 'Benitaka' and 'Rubi' table

Table 1. Mass and diameter of berries and mass and length of clusters of 'Isabel' grapes subjected to different treatments of $(S)$-cis-abscisic acid $(S$-ABA $){ }^{\mathrm{z}}$

\begin{tabular}{lrrrr}
\hline Treatments (concn in mg. $\left.\mathrm{L}^{-1}\right)$ & $\begin{array}{c}\text { Mass of } \\
\text { berries }(\mathrm{g})\end{array}$ & $\begin{array}{c}\text { Diam of } \\
\text { berries (mm) }\end{array}$ & $\begin{array}{c}\text { Mass of } \\
\text { clusters (g) }\end{array}$ & $\begin{array}{c}\text { Length of } \\
\text { clusters }(\mathrm{cm})\end{array}$ \\
\hline Control & $3.0 \mathrm{NS} \pm 0.1$ & $15.3 \mathrm{NS} \pm 0.1$ & $102.5 \mathrm{NS} \pm 8.3$ & $10.8 \mathrm{NS} \pm 0.3$ \\
$S$-ABA 200 (7 DAV) & $3.1 \pm 0.1$ & $15.6 \pm 0.2$ & $102.5 \pm 7.1$ & $10.5 \pm 0.3$ \\
$S$-ABA 400 (7 DAV) & $3.0 \pm 0.1$ & $15.6 \pm 0.2$ & $100.0 \pm 10.9$ & $10.6 \pm 0.3$ \\
$S$-ABA 200 (7 DAV) + 200 (15 DAFA) & $3.2 \pm 0.3$ & $15.9 \pm 0.6$ & $105.0 \pm 4.3$ & $10.3 \pm 0.2$ \\
$S$-ABA 400 (7 DAV) + 400 (15 DAFA) & $3.1 \pm 0.1$ & $16.1 \pm 0.6$ & $101.5 \pm 5.0$ & $10.6 \pm 0.4$ \\
\hline
\end{tabular}

${ }^{\mathrm{z}}$ Average of 2011 and 2012 seasons. Means within columns followed by different letters differ significantly by Scott-Knott's test $(P<0.05)$.

$7 \mathrm{DAV}=7 \mathrm{~d}$ after veraison; $15 \mathrm{DAFA}=15 \mathrm{~d}$ after the first application; $\mathrm{NS}=$ nonsignificant. 
grapes, the application of $S$-ABA also did not alter the diameter of berries or mass and length of clusters (Roberto et al., 2012, 2013).

Regarding the berry color attributes, clusters that received $S$-ABA application, particularly those that were treated with two applications, independent of the concentration, had the lowest $L^{*}$ (lightness) (Table 2), which indicates that 'Isabel' grape berries subjected to these treatments showed a darker skin color. Similar results were observed in 'Red Globe', 'Flame Seedless', 'Crimson Seedless', and 'Hongisul' table grapes (Peppi et al., 2007, 2008; Peppi and Fidelibus, 2008; Shin and Park, 2012).

Grapes treated with $S$-ABA had lower $C^{*}$ (chroma), indicating treated fruits had a slightly less pure color. Lower mean chroma values were also observed in 'Flame Seedless' and 'Crimson Seedless' grapes with $S$ ABA application (Cantín et al., 2007; Peppi et al., 2006). However, an effect on this variable in 'Benitaka' grapes treated with $S$-ABA was not found (Roberto et al., 2012). The hue $\left(h^{\circ}\right)$ is the angular component of the polar representation of CIELAB coordinates, in which the value represents a point on a color group (Hanbury and Serra, 2002). Analysis of the hue means did not reveal significant differences between treatments.

According to the results, all $S$-ABA treatments improved color attributes of 'Isabel' grape when compared with the control. However, as reported by Peppi et al. (2006), the increase in anthocyanin concentration is not linearly correlated with berry color, which explains the results observed in this work (Table 3). In general, S-ABA application resulted in increased anthocyanin concentrations in both berries and juices and compared with the control, the means almost doubled in juice produced with $S$-ABA-treated grapes; thus, a juice with better characteristics was obtained.

$S$-ABA at $400 \mathrm{mg} \cdot \mathrm{L}^{-1}$, applied once or twice, was shown to be more efficient to increase anthocyanin on grape juice, and it shows that, as stated by Peppi et al. (2006), the effect of certain cultural practices on berry color should consider measuring both color and skin anthocyanin concentrations, especially if the control fruits are relatively well colored. Black-colored grapes such as 'Isabel' usually present berries covered all over with dark color at full maturity, and the effect of $S$-ABA application by measuring only skin color might be not so precise. Besides, other factors such as chemical residues and wax coating in berries may also interfere with colorimeter readings.

The increase in ABA levels at around the time of veraison is consistent with it having a role in the control of berry ripening (Wheeler et al., 2009), resulting from increased expression of the key anthocyanin pathway enzyme UDP-glucose:flavonoid 3-Oglucosyltransferase (He et al., 2010). Thus, the application of exogenous ABA enhances the accumulation of anthocyanins (Ban et al., 2003; Jeong et al., 2004).

The application of $S$-ABA also increased the anthocyanin concentration in other cultivars, especially on table grapes such as 'Flame Seedless' (Peppi and Fidelibus, 2008), Red Globe' (Peppi et al., 2007), 'Alachua' and 'Noble' (Sandhu et al., 2011), and 'Hongisul' (Shin and Park, 2012).

The berry total polyphenol concentration was not significantly different between treatments (Table 3). Juice from $S$-ABA-treated grapes had higher concentrations of total polyphenols; however, it seems that this effect is dependent of the cultivar. For 'Noble' grape, the use of $S$-ABA provided $30 \%$ increase in

Table 2. Lightness $\left(L^{*}\right)$, chroma $\left(C^{*}\right)$, and hue angle $\left(h^{\circ}\right)$ of 'Isabel' berries subjected to different treatments of $(S)$-cis-abscisic acid $\left(S\right.$-ABA). ${ }^{\mathrm{z}}$

\begin{tabular}{lccr}
\hline Treatments (concn in $\mathrm{mg} \cdot \mathrm{L}^{-1}$ ) & $L^{*}$ & $C^{*}$ & \multicolumn{1}{c}{$h^{\circ}$} \\
\hline Control & $27.7 \pm 0.7 \mathrm{a}$ & $3.9 \pm 0.9 \mathrm{a}$ & $105.7 \mathrm{NS} \pm 17.2$ \\
$S$-ABA 200 (7 DAV) & $25.2 \pm 0.6 \mathrm{~b}$ & $2.0 \pm 0.2 \mathrm{~b}$ & $127.9 \pm 16.7$ \\
S-ABA 400 (7 DAV) & $25.4 \pm 0.4 \mathrm{~b}$ & $2.1 \pm 0.3 \mathrm{~b}$ & $124.6 \pm 13.6$ \\
S-ABA 200 (7 DAV) + 200 (15 DAFA) & $24.5 \pm 0.5 \mathrm{c}$ & $2.1 \pm 0.2 \mathrm{~b}$ & $126.6 \pm 14.2$ \\
S-ABA 400 (7 DAV) + 400 (15 DAFA) & $24.1 \pm 0.4 \mathrm{c}$ & $2.1 \pm 0.2 \mathrm{~b}$ & $137.2 \pm 7.2$ \\
\hline
\end{tabular}

${ }^{{ }^{2} \text { Average of } 2011 \text { and } 2012 \text { seasons. Means within columns followed by different letters differ significantly }}$ by Scott-Knott's test $(P<0.05)$.

$L^{*}=$ lightness; $C^{*}=$ chroma; $h^{\circ}=$ hue angle; $7 \mathrm{DAV}=7 \mathrm{~d}$ after veraison; $15 \mathrm{DAFA}=15 \mathrm{~d}$ after the first application; $\mathrm{NS}=$ nonsignificant.

Table 3. Total anthocyanins and polyphenols of berries and whole juice of 'Isabel' grapes subjected to different treatments of $(S)$-cis-abscisic acid $(S$-ABA $){ }^{\mathrm{z}}$

\begin{tabular}{|c|c|c|c|c|}
\hline \multirow[b]{2}{*}{ Treatments (concn in $\mathrm{mg} \cdot \mathrm{L}^{-1}$ ) } & \multicolumn{2}{|c|}{ Total anthocyanins } & \multicolumn{2}{|c|}{ Total polyphenols } \\
\hline & $\begin{array}{c}\text { Berries } \\
(\mathrm{mg} / 100 \mathrm{~g})\end{array}$ & $\begin{array}{c}\text { Juice } \\
\left(\mathrm{mg} \cdot \mathrm{L}^{-1}\right)\end{array}$ & $\begin{array}{c}\text { Berries } \\
(\mathrm{mg} / 100 \mathrm{~g})\end{array}$ & $\begin{array}{c}\text { Juice } \\
\left(\mathrm{g} \cdot \mathrm{L}^{-1}\right)\end{array}$ \\
\hline Control & $10.0 \pm 1.3 \mathrm{~b}$ & $51.8 \pm 3.4 \mathrm{c}$ & $27.9 \mathrm{NS} \pm 3.0$ & $0.1 \pm 0.02 \mathrm{~b}$ \\
\hline$S$-ABA 200 (7 DAV) & $16.5 \pm 0.9 \mathrm{a}$ & $75.6 \pm 5.4 \mathrm{~b}$ & $27.2 \pm 3.6$ & $0.2 \pm 0.01 \mathrm{a}$ \\
\hline$S$-ABA 400 (7 DAV) & $17.5 \pm 2.0 \mathrm{a}$ & $89.9 \pm 7.6 \mathrm{a}$ & $26.7 \pm 0.7$ & $0.3 \pm 0.04 \mathrm{a}$ \\
\hline$S$-ABA $200(7 \mathrm{DAV})+200(15 \mathrm{DAFA})$ & $17.5 \pm 1.3 \mathrm{a}$ & $82.3 \pm 14.6 \mathrm{~b}$ & $30.6 \pm 2.0$ & $0.3 \pm 0.05 \mathrm{a}$ \\
\hline$S$-ABA $400(7 \mathrm{DAV})+400(15 \mathrm{DAFA})$ & $17.2 \pm 2.0 \mathrm{a}$ & $93.9 \pm 7.1 \mathrm{a}$ & $28.9 \pm 0.9$ & $0.3 \pm 0.03 \mathrm{a}$ \\
\hline
\end{tabular}

total polyphenols, whereas for 'Alachua' grape, no difference on application of this regulator was observed (Sandhu et al., 2011). The concentration of polyphenols in grapes is critical for the quality of its derivatives such as juice, because these organic compounds are responsible for the organoleptic characteristics [in particular, color (intensity and hue), flavor, and aroma] of the derivatives (Curvelo-Garcia, 1988; Kataoka et al., 1982; Lorrain et al., 2011; Ribichaud and Noble, 1990).

Sensory analysis showed no significant differences among $S$-ABA treatments, except for juice color, but all treatments differed with the control for all analyzed variables (Fig. 1). The highest mean for juice color, a characteristic related to the concentration of anthocyanins, was obtained from treatments with two applications of $S$-ABA independent of the concentration as well as with a single application of $S$-ABA at $400 \mathrm{mg} \cdot \mathrm{L}^{-1}$. These three treatments significantly differed from the single application of $S$-ABA at $200 \mathrm{mg} \cdot \mathrm{L}^{-1}$, which in turn was significantly different from the control, although, in relation to anthocyanin concentration on juice (Table 3 ), there was no difference between treatments with one or two applications of $S$-ABA at $200 \mathrm{mg} \cdot \mathrm{L}^{-1}$. It indicates that the effect of treatments to improve grape juice quality has to be evaluated not only by measuring berry color and anthocyanin concentrations, but also by analyzing the consumer acceptance. Such information combined provides a better understanding about how all these evaluations interact and what is essential for the establishment of a new cultivation technique when a grape juice with better characteristics is desired to be obtained.

Color is a major quality component of grapes for processing because, in most cases, a high intensity of skin color is related to a high concentration of anthocyanins (Boulton, 2001; Meullent et al., 2008; Parpinello et al., 2009). The juice of 'Isabel' grape needs to be blended with other grape cultivars because of the lack of its pigmentation. Thus, the greater color intensity of 'Isabel' grape juice caused by increased concentration of anthocyanins from $S$-ABA application resulted in greater acceptance by tasters (Fig. 1); consequently, the blend of juices from other pigmentproducing grapes seems to be no longer necessary. This is a very important issue because, as a rule, these cultivars are less productive and thus less profitable than 'Isabel' grape and have consequently been sidelined by growers.

In some areas, ethephon is usually applied to red-colored table grapes as a technique to improve berry color, but eventually, it can cause the clusters to soften (Szyjewicz et al., 1984) reducing the commercial value of exported grapes, but this effect is not consistent (Peppi et al., 2007). In addition, although ethephon is applied to clusters, because it releases ethylene, it can drift and be absorbed by leaves, causing defoliation, which adversely affects vine sprouting in the subsequent harvest. For these reasons, ethephon 


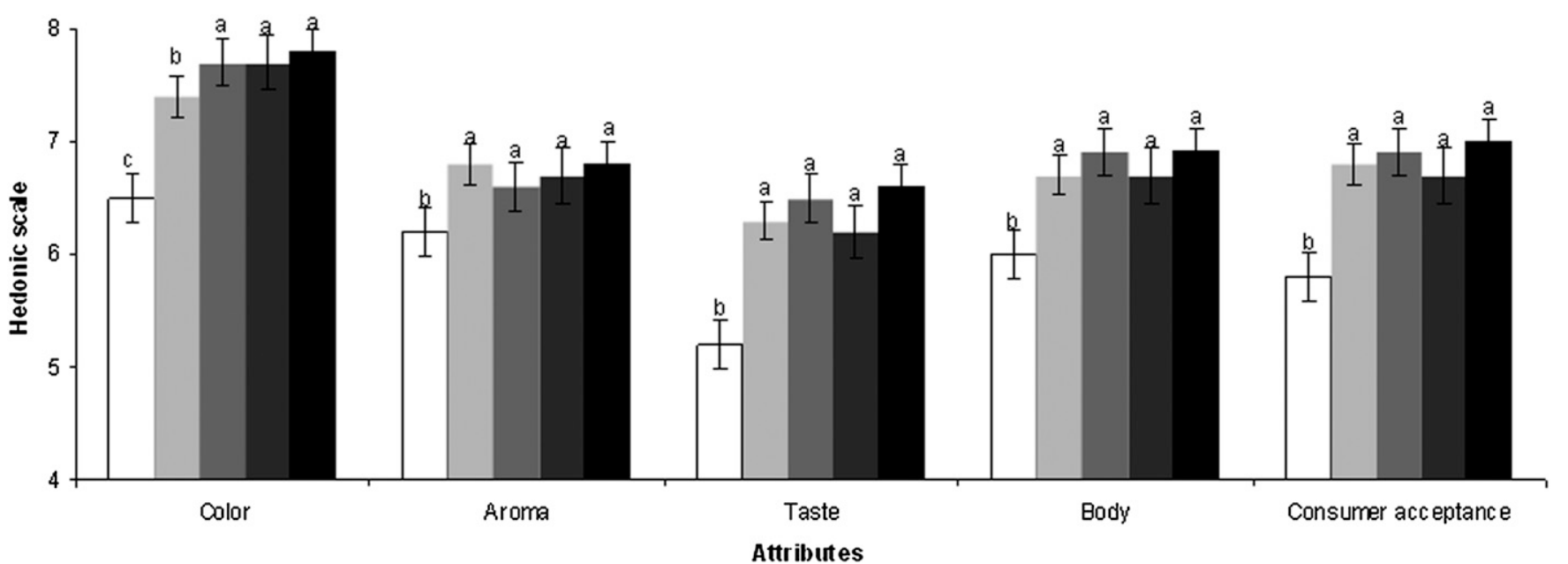

\section{$\square$ Control}

- $S-A B A 400 \mathrm{mg} \cdot \mathrm{L}^{-1}(7 \mathrm{DAV})$

$S-A B A 400 \mathrm{mg}^{-1} \mathrm{~L}^{-1}(7 \mathrm{DAV}) \div 400 \mathrm{mg}^{-1} \mathrm{~L}^{-1}(15 \mathrm{DAFA})$
II $-\mathrm{ABA} 200 \mathrm{mg} \cdot \mathrm{L}^{-1}(7 \mathrm{DAV})$

- $S-A B A 200 \mathrm{mg} \cdot \mathrm{L}^{-1}(7 \mathrm{DAV}) \div 200 \mathrm{mg} \cdot \mathrm{L}^{-1}(15 \mathrm{DAFA})$

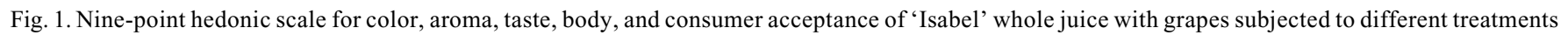
with $(S)$-cis-abscisic acid (S-ABA). Average of 2011 and 2012 seasons. Note: means within bars followed by different letters differ significantly by Scott-Knott's test $(P<0.05) .7 \mathrm{DAV}=7 \mathrm{~d}$ after veraison; $15 \mathrm{DAFA}=15 \mathrm{~d}$ after the first application. Nine-point hedonic scale: dislike extremely $(1)$ to like extremely (9).

application to improve color characteristics of grapes is not a current practice in many countries such as in Brazil and, depending of local regulations, this plant growth regulator is just registered for vine defoliation and not for grape color improvement. Thus, $S$-ABA application has a great potential to improve quality of whole juice of 'Isabel' grapes, especially in warm growing areas, but its use has to be particularly analyzed regarding additional production costs and prices paid by grape processors.

Based on these results, it was observed that the use of $S$-ABA has an increasing effect on anthocyanins and polyphenol concentration in berry and juice of 'Isabel' grape. A single application of $S$-ABA at $400 \mathrm{mg} \cdot \mathrm{L}^{-1}$ at 7 DAV or a double application (7 DAV +15 DAFA) provides a significant increase of anthocyanin concentration in whole juice, results that can be evidenced in the sensory analysis. However, considering the costs involved in the application of this growth regulator (e.g., labor and machinery), a single application of $S$-ABA at $400 \mathrm{mg} \cdot \mathrm{L}^{-1}$ at 7 DAV is sufficient to significantly increase the concentration of anthocyanins in 'Isabel' grape juices.

\section{Literature Cited}

Ban, T., M. Ishimaru, S. Kobayashi, S. Shiozaki, N. Goto-Yamamoto, and S. Horiuchi. 2003. Abscisic acid and 2,4-dichlorophenoxyacetic acid affect the expression of anthocyanin biosynthetic pathway genes in 'Kyoho' grape berries. J. Hort. Sci. Biotechnol. 78:586-589.

Borges, R.S., G.A. da Silva, S.R. Roberto, A.M. de Assis, and L.Y. Yamamoto. 2013. Phenolic compounds, favorable oxi-redox activity and juice color of 'Concord' grapevine clones. Sci. Hort. 161:188-192.
Boulton, R. 2001. The copigmentation of anthocyanins and its role in the color of red wine: A critical review. Amer. J. Enol. Viticult. 52: 67-84.

Camargo, U.A., J.D.G. Maia, and P.S. Ritschel. 2010. Novas cultivares brasileiras de uva. Bento Gonçalves: Embrapa Uva e Vinho [New Brazilian grape cultivars]. Embrapa Uva e vinho, Bento Gonçalves.

Cantín, M.C., M.W. Fidelibus, and C.H. Crisosto. 2007. Application of abscisic acid (ABA) at veraison advanced red color development and maintained postharvest quality of 'Crimson Seedless' grapes. Post. Biol. Tech. 46:237-241.

Clemente, E. and D. Galli. 2013. Stability evaluation of anthocyanin extracted from processed grape residues. Intl. J. of Sciences 2:12-18.

Curvelo-Garcia, A.S. 1988. Controlo de Qualidade dos Vinhos. Química Enológica-Métodos Analíticos. Lisboa: Instituto da Vinha e do Vinho [Quality control of wines. Enological chemistryAnalytical methods]. Institute of Vine and Wine, Lisbon, Portugal.

Francis, F.J. 2000. Anthocyanins and betalains: Composition and applications. Cereal. Food. World 45:208-213.

Han, D.H., S.M. Lee, C.H. Lee, and S.B. Kim. 1996. Effects of ABA and ethephon treatments on coloration and fruit quality in Kyoho grape. J. Kor. Soc. Hort. Sci. 37:416-420.

Hanbury, A. and J. Serra. 2002. Mathematical morphology in the CIELAB space. Image Anal. Stereol. 21:201-206.

He, F., L. Mu, G.L. Yan, N.N. Liang, Q.H. Pan, J. Wang, M.J. Reeves, and C.Q. Duan. 2010. Biosynthesis of anthocyanins and their regulation in colored grapes. Molecules 15:90579091.

Hiratsuka, S., H. Onodera, Y. Kawai, T. Kubo, H. Itoh, and R. Wada. 2001. ABA and sugar effects on anthocyanin formation in grape berry cultured in vitro. Sci. Hort. 90:121-130.

Jeong, S.T., N. Goto-Yamamoto, S. Kobayashi, and M. Esaka. 2004. Effects of plant hormones and shading on the accumulation of and the expression of anthocyanin biosynthetic genes berry skins. Plant Sci. 167:247-252.

Kataoka, A., N. Sugiura, and T. Utsunomiya. 1982. Effect of abscisic acid and defoliation on anthocyanin accumulation in Kyoho grapes (Vitis vinifera L. $\times$ V. labruscana BAILEY). Vitis 2:325-332.

Lancaster, J.E., C. Lister, P.F. Reay, and C.M. Triggs. 1997. Influence of pigment composition on skin color in a wide range of fruits and vegetables. J. Amer. Soc. Hort. Sci. 122:594 598.

Lee, J.C. and T. Tomana. 1980. Physiological study on anthocyanin development in grapes. II. Effect of sucrose, abscisic acid and indoleacetic acid on the anthocyanin development in Kyoho grape (Vitis labruscana). J. Kor. Soc. Hort. Sci. 21:158-163.

Lorrain, B., K. Chira, and P. Teissedre. 2011. Phenolic composition of Merlot and CabernetSauvignon grapes from Bordeaux vineyard for 2009-vintage: Comparison to 2006, 2007 and 2008 vintages. Food Chem. 126:1991-1999.

MacGuire, R.G. 1992. Reporting of objective color measurements. HortScience 27:1254-1255.

Markakis, P. 1982. Stability of anthocyanins in foods. In: Anthocyanins as food colors. New York, NY.

Matsushima, J., S. Hiratsuka, N. Taniguchi, R. Wada, and N. Suzaki. 1989. Anthocyanin accumulation and sugar content in the skin of grape cultivar Olympia treated with ABA. J. Jpn. Soc. Hort. Sci. 58:551-555.

Meullent, J.F., C. Lovely, R. Threlfall, J.R. Morris, and R.K. Striegler. 2008. An ideal point density plot method for determining an optimal sensory profile for Muscadine grape juice. Food Qual. Prefer. 19:210-219.

Naczk, M. and F. Shahidi. 2004. Extractions and analysis of phenolics in food. J. Chromatography 1054:95-111.

Nixdorf, S.L. and I. Hermosín-Gutiérrez. 2010. Brazilian red wines made from the hybrid grape 
cultivar Isabel: Phenolic composition and antioxidant capacity. Anal. Chim. Acta 659:208-215.

Orak, H.H. 2007. Total antioxidant activities, phenolics, anthocyanins, polyphenoloxidase activities of selected red grape cultivars and their correlations. Sci. Hort. 111:235-241.

Owen, S.J., M.D. Lafond, P. Bowen, C. Bogdanoff, K. Usher, and S.R. Abrams. 2009. Profiles of abscisic acid and its catabolites in developing Merlot grape (Vitis vinifera) berries. Amer. J. Enol. Viticult. 60:277-284.

Parpinello, G.P., A. Versari, F. Chinnici, and S. Galassi. 2009. Relationship among sensory descriptors, consumer preference and color parameters of Italian Novello red wines. Food Res. Intl. 42:1389-1395.

Peppi, M.C. and M.W. Fidelibus. 2008. Effects of Forchlorfenuron and abscisic acid on the quality of 'Flame Seedless' grapes. HortSci. 43:173176.

Peppi, M.C., M.W. Fidelibus, and N. Dokoozlian. 2006. Abscisic acid application timing and concentration affect firmness, pigmentation and color of 'Flame Seedless' grapes. HortScience 41:1440-1445.

Peppi, M.C., M.W. Fidelibus, and N. Dokoozlian. 2007. Application timing and concentration of abscisic acid affect the quality of 'Redglobe' grapes. J. Hort. Sci. Biotechnol. 82:304 310.

Peppi, M.C., M.A. Walker, and M.W. Fidelibus. 2008. Application of abscisic acid rapidly upregulated UFGT gene expression and improved color of grape berries. Vitis 47:11-14.
Rastija, V., G. Srecnik, and M. Saric. 2009. Polyphenolic composition of Croatian wines with different geographical origins. Food Chem. 115:54-60.

Ribichaud, J.L. and A.C. Noble. 1990. Astringency and bitterness of selected phenolic in wines. J. Sci. Food Agr. 53:343-353.

Roberto, S.R., A.M. de Assis, L.Y. Yamamoto, L.C.V. Miotto, R. Koyama, A.J. Sato, and R.S. Borges. 2013. Ethephon use and application timing of abscisic acid for improving color of 'Rubi' table grape. Pesquisa Agropecu. Bras. 48:797-800.

Roberto, S.R., A.M. de Assis, L.Y. Yamamoto, L.C.V. Miotto, A.J. Sato, R. Koyama, and W. Genta. 2012. Application timing and concentration of abscisic acid improve color of 'Benitaka' table grape. Sci. Hort. 142:44-48.

Sandhu, A.K., D.J. Gray, J. Lu, and L. Gu. 2011 Effects of exogenous abscisic acid on antioxidant capacities, anthocyanins and flavonol contents of muscadine grape (Vitis rotundifolia) skins. Food Chem. 126:982-988.

Sato, A.J., B.S. Jubileu, C.E. Santos, R. Bertolucci, R.A.L. Silva, M. Carielo, M.C. Guiraud, I.C.B. Fonseca, and S.R. Roberto. 2009. Evolução da maturação e características fisico-químicas de uvas da cultivar Isabel sobre diferentes portaenxertos na região Norte do Paraná [Evolution of maturation and physicochemical characteristics of the Isabel grape cultivar on different rootstocks in northern Paraná state]. Semina 30:11-20.

Segade, S.R., E.S. Vázquez, and E.D. Losada. 2008. Influence of ripeness grade on accumulation and extractability of grape skin anthocyanins in different cultivars. J. Food Compos. 21:599607.

Shin, K.H. and H.S. Park. 2012. Fruit color improvement by ABA treatment and determination of harvesting time in 'Hongisul' grapes. Kor. J. Hort. Sci. Technol. 3:256-260.

Siewers, V., L. Kokkelink, J. Smedsgaard, and P. Tudzynski. 2006. Identification of an abscisic acid gene cluster in the grey mould Botrytis cinerea. Appl. Environ. Microbiol. 72:46194626.

Singleton, V.L., R. Orthofer, and R.M. LamuelaRaventós. 1999. Analysis of total phenols and other oxidation substrates and antioxidants by means of Folin-Ciocalteu reagent. In Packer, L. (ed.). Methods in enzymology, oxidant and antioxidants. Academic Press, San Diego, CA.

Szyjewicz, E., N. Rosner, and W.M. Kliewer. 1984. Ethephon [(2-chloroethyl) phosphonic acid, ethrel, CEPA] in viticulture-A review. Amer. J. Enol. Viticult. 35:117-123.

Villanueva, N.D.M., A.J. Petenateb, and M.A.A.P. Silva. 2005. Performance of hybrid hedonic scale as compared to the traditional hedonic, self-adjusting and ranking scales. Food Qual. Prefer. 16:691-703.

Wheeler, S., B. Loveys, C. Ford, and C. Davies. 2009. The relationship between the expression of abscisic acid biosynthesis genes, accumulation of abscisic acid and the promotion of Vitis vinifera $\mathrm{L}$. berry ripening by abscisic acid. Aust. J. Grape Wine Res. 15:195-204. 